months of age and were potentially preventable by MenB vaccine vaccination.

During 2012-13 through 2014-15, a total of $25(67.5 \%)$ of $37 \mathrm{MenW}$ cases in infants were confirmed by culture; 18 $(49 \%)$ of these cases were phenotypically characterized as MenW:2a, a surrogate phenotypic marker for the hypervirulent ST11 MenW strain. Ten (48\%) of the 21 isolates from infants during 2014-15 were MenW:2a, compared with 1 (25\%) of 4 during 2012-13 (Figure, panel B). Final diagnoses reported for 20 infants included meningitis $(n=10$ $[50 \%])$, septicemia $(n=3[15 \%])$, both meningitis and septicemia $(n=5[10 \%])$, and septic arthritis $(n=1[2 \%])$. From 1998-99 through 2014-15, six infants died of MenW IMD (case-fatality rate $3.4 \%$ ). Four of those deaths occurred during the Hajj outbreak; only 1 death attributed to MenW occurred during the 3 most recent epidemiologic years.

The rapid increase in MenW cases among infants, particularly most recently (2014-15), is cause for concern, and the contemporaneous introduction of MenB vaccine into the national immunization schedule is timely. Although this vaccine is licensed for prevention of MenB disease, the antigens are not specific to this capsular group and could protect against other meningococcal capsular groups that share the same antigens as those in the vaccine. Infants and toddlers immunized with MenB vaccine are expected to develop bactericidal antibodies against ST11 MenW. Data on age distribution suggest that $\approx 70 \%$ of MenW cases in infants could be prevented by MenB vaccination at 2 and 4 months of age. Beginning in mid2016, the MenB vaccine booster for children 1 year of age is also expected to protect toddlers, for whom MenW cases have also rapidly increased (3).

\section{Acknowledgments}

We appreciate and acknowledge the hard work of the surveillance team at Public Health England Colindale, the laboratory staff at Public Health England's Meningococcal Reference Unit, and local health protection teams.

\section{References}

1. Ladhani SN, Giuliani MM, Biolchi A, Pizza M, Beebeejaun K, Lucidarme J, et al. Effectiveness of meningococcal B vaccine against endemic hypervirulent Neisseria meningitidis W strain, England. Emerg Infect Dis. 2016;22:309-11. http://dx.doi.org/10.3201/eid2202.150369

2. Ladhani SN, Beebeejaun K, Lucidarme J, Campbell H, Gray S, Kaczmarski E, et al. Increase in endemic Neisseria meningitidis capsular group $\mathrm{W}$ sequence type 11 complex associated with severe invasive disease in England and Wales. Clin Infect Dis. 2015;60:578-85. http://dx.doi.org/10.1093/cid/ciu881

3. Campbell H, Saliba V, Borrow R, Ramsay M, Ladhani SN. Targeted vaccination of teenagers following continued rapid endemic expansion of a single meningococcal group $\mathrm{W}$ clone (sequence type 11 clonal complex), United Kingdom 2015. Euro Surveill. 2015;20:21188.

http://dx.doi.org/10.2807/1560-7917.ES2015.20.28.21188

4. Ramsay ME, Andrews NJ, Trotter CL, Kaczmarski EB, Miller E. Herd immunity from meningococcal serogroup C conjugate vaccination in England: database analysis. BMJ. 2003;326:365-6. http://dx.doi.org/10.1136/bmj.326.7385.365

5. Trotter CL, McVernon J, Ramsay ME, Whitney CG, Mulholland EK, Goldblatt D, et al.; SAGE subgroup. Optimising the use of conjugate vaccines to prevent disease caused by Haemophilus |influenzae type b, Neisseria meningitidis and Streptococcus pneumoniae. Vaccine. 2008;26:4434-45. http://dx.doi.org/10.1016/j.vaccine.2008.05.073

6. Ladhani SN, Christensen H, Trotter C, Ramsay ME. Indirect impact of an adolescent meningococcal ACWY conjugate vaccine programme in England with and without catch-up: a transmission dynamic model. Presented at: 13th Congress EMGM, European Meningococcal Disease Society; 2015 September 14-17; Amsterdam, the Netherlands. Abstract 5.01. http://emgm.eu/meetings/ emgm2015/EMGM2015_programme.pdf

7. Public Health England. Infection report. Invasive meningococcal disease (laboratory reports in England): 2014/2015 annual data by epidemiological year. Health Protection Report. 2015;9(38) [cited 2016 Mar 23]. https://www.gov.uk/government/uploads/system/ uploads/attachment_data/file/498057/hpr3815_imd-crrctd.pdf

Address for correspondence: Shamez Ladhani, Public Health England, Immunisation, Hepatitis and Blood Safety Department, 61 Colindale Ave, London NW9 5EQ, UK; email: shamez.ladhani@phe.gov.uk

\title{
Novel Reassortant Avian Influenza A(H5N6) Viruses in Humans, Guangdong, China, 2015
}

\section{Yong-Yi Shen, ${ }^{1}$ Chang-Wen Ke, ${ }^{1}$ Qian Li, ${ }^{1}$ Run-Yu Yuan, Dan Xiang, Wei-Xin Jia, Yun-Di Yu, Lu Liu, Can Huang, Wen-Bao Qi, Reina Sikkema, Jie Wu, Marion Koopmans, Ming Liao}

Author affiliations: Key Laboratory of Zoonosis Prevention and Control of Guangdong Province, Guangzhou (Y.-Y. Shen); College of Veterinary Medicine, South China Agricultural University, Guangzhou, China (Y.-Y. Shen, Q. Li, W.-X. Jia, Y.-D. Yu, W.-B. Qi, M. Liao); Guangdong Provincial Center for Disease Control and Prevention, Guangzhou (C.-W. Ke, R.-Y. Yuan, J. Wu); Shantou University Medical College, Shantou, China (D. Xiang, L. Liu, C. Huang); Key Laboratory of Veterinary Vaccine Innovation of the Ministry of Agriculture, Guangzhou (W.-B. Qi); National Institute of Public Health and the Environment, Bilthoven, the Netherlands (R. Sikkema, M. Koopmans); National and Regional Joint Engineering Laboratory for Medicament of Zoonosis Prevention and Control, Guangzhou (M. Liao)

DOI: http://dx.doi.org/10.3201/eid2208.160146

${ }^{1}$ These authors contributed equally to this article. 
To the Editor: Avian influenza A(H5N6) influenza viruses have circulated among poultry in southern ( Jiangxi, Guangdong) and western (Sichuan) provinces of China since $2013(1,2)$. In 2014, outbreaks of H5N6 virus infection occurred among poultry in China, Laos, and Vietnam (1). In April 2014, the first case of highly pathogenic H5N6 infection among humans was detected in Sichuan Province (3); the second case was detected on December 3, 2014, in Guangdong Province (4). In December 2015, 4 humans in Guangdong Province were infected with H5N6 influenza $(5,6)$.

To study the genetic basis of continuing human infections with this avian influenza subtype, we sequenced the complete genomes of 2 of the 4 human H5N6 isolates obtained in December 2015 in Guangdong Province. We compared these sequences with those of 1 H6N6 and 8 H5N6 influenza viruses isolated from birds in live poultry markets in this region during 2013-2015 (online Technical Appendix, http://wwwnc.cdc.gov/ EID/article/22/8/16-0146-TechApp1.pdf) and other published genomes of H5, H6N6, and H9N2 avian influenza viruses (online Technical Appendix Table). Phylogenetic analyses of the hemagglutinin (HA) genes showed that all human H5N6 isolates belonged to clade 2.3.4.4 (online Technical Appendix Figure 1, panel A). HA and neuraminidase (NA) genes of some H5N6 viruses isolated in Guangdong Province during 2013-2014 were in the Sichuan-like lineage, but all of those from 2015 were in the Jiangxi-like lineage (online Technical Appendix Figure 1, panels A, B).
Despite the similarities of the HA and NA genes, the 6 internal genes from the 2 human isolates from 2015, A/Guangdong/ZQ874/2015 (H5N6) and A/Guangdong/ SZ872/2015 (H5N6) were different from 2 human H5N6 isolates from 2014, A/Sichuan/26221/2014 (H5N6) and A/Guangzhou/39715/2014 (H5N6). The polymerase basic (PB) 2 gene from isolate A/Guangdong/ZQ874/2015 (H5N6) appears to have derived from an H6N6 virus isolated from a duck; all other genes in this isolate were derived from H5N6 viruses that have been circulating among poultry since 2013 (online Technical Appendix Figure 1, panel C; online Technical Appendix Figure 2). This isolate showed high nucleotide identity to 6 of the 8 genes (HA, 96.5\%; NA, 98.2\%; nucleoprotein (NP), 98.5\%; polymerase acidic (PA), 98.3\%; PB1, 98.1\%; PB2, 98.4\%) of the isolate A/chicken/Guandong/ FG594/2015 (H5N6); the identities of the matrix (M) and nonstructural protein (NSP) genes were $76.2 \%$ and $79.8 \%$ similar, respectively. This finding suggests that undetected reassortants of H5N6 may exist. The other human isolate, A/Guangdong/SZ872/2015 (H5N6), showed high nucleotide identity with A/Yunnan/0127/2015 (H5N6), an isolate collected from a person in Yunnan Province (GenBank accession nos. KT963053-60; online Technical Appendix Table), for all 8 genes (HA, 97.2\%; M, 97.7\%; NA, 96.8\%; NP, 98.3\%; NSP, 93.2\%; PA, 95.9\%; PB1, 96.9\%; PB2, 94.0\%). The 6 internal genes of A/Guangdong/SZ872/2015 (H5N6) appear to have come from the enzootic H9N2 (ZJ-HJ/07) virus lineage (online Technical Appendix Figure 1, panel C). These

\begin{tabular}{|c|c|c|c|c|c|c|}
\hline Phenotypic consequences & Mutations & $\begin{array}{l}\text { A/Sichuan// } \\
26221 / 2014\end{array}$ & $\begin{array}{c}\text { A/Guangzhou/ } \\
39715 / 2014\end{array}$ & $\begin{array}{c}\text { A/Yunan/ } \\
0127 / 2015 \\
\end{array}$ & $\begin{array}{l}\text { A/Guangdong/ } \\
\text { SZ872/2015 }\end{array}$ & $\begin{array}{c}\text { A/Guangdong/ } \\
\text { ZQ874/2015 }\end{array}$ \\
\hline \multicolumn{7}{|l|}{ HA gene } \\
\hline Altered receptor specificity & S128P & $\mathrm{T}$ & $\mathrm{P}$ & $\mathrm{P}$ & $\mathrm{P}$ & $P$ \\
\hline Increased a 2,6-SA recognition & S137A & A & A & A & A & A \\
\hline Removal of the $158 \mathrm{~N}$ & T160A & A & $\mathrm{T}$ & A & A & A \\
\hline glycosylation & Q226L & & $Q$ & $\mathrm{Q}$ & $Q$ & $Q$ \\
\hline Cleavage site sequence & Not applicable & REKRRKR $\downarrow G$ & REKRRKR $\downarrow G$ & REKRRKR $\downarrow G$ & REKRRKR $\downarrow G$ & REKRRKR $\downarrow G$ \\
\hline \multicolumn{7}{|l|}{ NA gene } \\
\hline $59-69 \mathrm{del}$ & TIINNHPQNNF & No & Yes & Yes & Yes & Yes \\
\hline \multirow[t]{2}{*}{ Oseltamivir resistance } & $\mathrm{H} 274 \mathrm{Y}$ & $\mathrm{H}$ & $\mathrm{H}$ & $\mathrm{H}$ & $\mathrm{H}$ & $\mathrm{H}$ \\
\hline & N294S & $\mathrm{N}$ & $\mathrm{N}$ & $\mathrm{N}$ & $\mathrm{N}$ & $\mathrm{N}$ \\
\hline \multicolumn{7}{|l|}{ PB2 } \\
\hline Increased pathogenicity in & L89V & V & V & V & V & V \\
\hline mice & E627K & E & $\mathrm{K}$ & $\mathrm{K}$ & $\mathrm{E}$ & $\mathrm{E}$ \\
\hline Increased virulence and & G309D, T339K & DMGV & DTGV & DKGV & DKGV & DKGV \\
\hline $\begin{array}{l}\text { replication in mice } \\
\text { Enhanced transmission }\end{array}$ & R477G, 1495V & $N$ & $D$ & $\mathrm{D}$ & $\mathrm{D}$ & $\mathrm{N}$ \\
\hline \multicolumn{7}{|l|}{ NS1 } \\
\hline Increased virulence in mice & D92E & $\mathrm{E}$ & $\mathrm{E}$ & D & D & $\mathrm{E}$ \\
\hline $\begin{array}{l}\text { PDZ-motif } \\
\text { Increased virulence in mice }\end{array}$ & $\begin{array}{c}\text { Not applicable } \\
\text { P42S }\end{array}$ & $\begin{array}{c}\text { ESEV } \\
S\end{array}$ & $\begin{array}{c}\text { ESEV } \\
S\end{array}$ & $\begin{array}{c}\mathrm{KPEV} \\
\mathrm{S}\end{array}$ & $\begin{array}{c}\mathrm{KPEV} \\
\mathrm{S}\end{array}$ & $\begin{array}{c}\text { ESEV } \\
S\end{array}$ \\
\hline \multicolumn{7}{|l|}{ M2 } \\
\hline $\begin{array}{l}\text { Antiviral resistance } \\
\text { (amantadine) }\end{array}$ & S31N & $s$ & $s$ & $\mathrm{~N}$ & $\mathrm{~N}$ & S \\
\hline
\end{tabular}


findings show that the circulating H5N6 virus in southern China has reassorted with enzootic H6N6 and H9N2 viruses, resulting in new $\mathrm{H} 5 \mathrm{~N} 6$ viruses that are capable of infecting humans.

We compared the 2 newly sequenced genomes with 3 available genomes of human influenza virus strains in public databases to determine if they had attained key molecular features associated with increased virulence in mammals, mammalian transmissibility, and antiviral resistance (Table). The HA gene cleavage site encoded by all 5 isolates from humans showed a multiple basic amino acid motif (REKRRKR $\downarrow$ G), which indicates high pathogenicity in poultry. The viruses isolated from humans in 2014 had no mutations associated with reduced sensitivity to adamantine antiviral drugs, but 2 of the 3 viruses isolated in 2015 have the $31 \mathrm{~N}$ amino acid in M2, suggesting that those 2 viruses have acquired resistance. Thus, this virus lineage could be a great threat to public health.

Although H9N2 is not highly pathogenic in poultry, it provides internal genes for the recent emergence of many novel avian influenza viruses that infect humans, such as the H5N6 virus in this study, as well as the H7N9 $(7,8)$ and H10N8 (9) viruses. Infection with H6 subtype viruses results in no clinically significant signs of disease in poultry (10), but co-circulation of these viruses with other subtypes among poultry results in transfer of internal genes. This reassortment has resulted in a major increase in genetic diversity among the H5N6 viruses that cause human infections; therefore, low-pathogenicity viruses in poultry should also be controlled in poultry.

In summary, we isolated 2 novel reassortant H5N6 viruses from 2 patients in Guangdong Province, China. The internal genes of these strains are different from those found in the first wave of H5N6 infections in 2014. The PB2 of 2 human isolate A/Guangdong/ZQ874/2015 (H5N6) appears to have been derived from a duck H6N6 virus, and all other genes of this virus originated in circulating H5N6 viruses. In contrast, the 6 internal genes of the other human isolate, A/Guangdong/SZ872/2015 (H5N6), were derived from enzootic H9N2 viruses. Although human infection has been sporadic, the co-circulation and reassortment of this virus with other enzootic low pathogenicity influenza viruses has resulted in new reassortant viruses. Further surveillance of birds is needed to monitor the spread of this novel virus.

This study was supported by the National Natural Science Foundation of China (U1501212); Guangdong Natural Science Funds for Distinguished Young Scholar (2014A030306046), was a Key Project of the Agricultural Ministry (CARS42-G09), and the Modern Agriculture Talents Support Program (2012, no. 160).

\section{References}

1. Shen H, Wu B, Chen Y, Bi Y, Xie Q, Influenza A (H5N6) virus reassortant, Southern China, 2014. Emerg Infect Dis. 2015;21:1261-2.http://dx.doi.org/10.3201/eid2107.140838

2. Qi X, Cui L, Yu H, Ge Y, Tang F. Whole-genome sequence of a reassortant H5N6 avian influenza virus isolated from a live poultry market in China, 2013. Genome Announc. 2014;2:e00706-14. http://dx.doi.org/10.1128/genomeA.00706-14

3. World Health Organization. WHO China statement on H5N6. 7 May 2014 [cited 2016 Mar 28]. http://www.wpro.who.int/china/ mediacentre/releases/2014/20140507/en/

4. Mok CKP, Da Guan W, Liu XQ, Lamers MM, Li XB, Wang M, et al. Genetic characterization of highly pathogenic avian influenza A(H5N6) virus, Guangdong, China. Emerg Infect Dis. 2015;21:2268-71. http://dx.doi.org/10.3201/eid2112.150809

5. World Health Organization. Human infection with avian influenza A(H5N6) virus_China. 04 Jan 2016 [cited 2016 Mar 28]. http:/www.who.int/csr/don/4-january-2016-avian-influenza-china/en/

6. World Health Organization. Human infection with avian influenza A(H5N6) virus-China. 11 Jan 2016 [cited 2016 Mar 28]. http://www.who.int/csr/don/11-january-2016-avian-influenzachina/en/

7. Lam TT, Zhou B, Wang J, Chai Y, Shen Y, Chen X, et al. Dissemination, divergence and establishment of H7N9 influenza viruses in China. Nature. 2015;522:102-5. http://dx.doi.org/10.1038/ nature 14348

8. Lam TT-Y, Wang J, Shen Y, Zhou B, Duan L, Cheung C-L, et al. The genesis and source of the H7N9 influenza viruses causing human infections in China. Nature. 2013;502:241-4. http://dx.doi.org/10.1038/nature12515

9. Chen H, Yuan H, Gao R, Zhang J, Wang D, Xiong Y, et al. Clinical and epidemiological characteristics of a fatal case of avian influenza A H10N8 virus infection: a descriptive study. Lancet. 2014;383:714-21.http://dx.doi.org/10.1016/S0140-6736(14)60111-2

10. Zhao G, Lu X, Gu X, Zhao K, Song Q, Pan J, et al.

Molecular evolution of the H6 subtype influenza a viruses from poultry in eastern China from 2002 to 2010.Virol J. 2011;8:470. http://dx.doi.org/10.1186/1743-422X-8-470

Address for correspondence: Ming Liao, College of Veterinary Medicine, South China Agricultural University, Guangzhou, China; email: mliao@scau.edu.cn

\section{GOVDELIVERY
Manage your email alerts so you only receive content of interest to you.}

\author{
Sign up for an \\ online subscription: \\ wwwnc.cdc.gov/eid/subscribe.htm
}

